\title{
The interplay between theology and development: How theology can be related to development in post-modern society.
}

\section{John Klaasen ${ }^{1}$}

\section{Abstract}

This article attempts to make a contribution to the discourse of missiology by engaging critically with the much debated studies of theology and development. The two widely used definitions of development are analysed to point out commonalities and weaknesses. A theology of relationality is then introduced with reference to the Trinity, relationships and personhood. Some pointers then emerged to form a more integral understanding of development. I then make some connections between human and social development and the Trinity and perichoresis and to point out the missiological and ecclesiological implications for the mission of the church.

Keywords: Mission, ecclesiology, theology, development, relationality, perichoresis.

\section{Introduction}

Over the last two decades, development has become a major theme in the theological field. Both nationally and internationally, development studies have become part of the theological discourse. Development is situated within missiology and this article assumes that development is an integral part of missiology. The conclusions drawn in this article takes the critical relationship that development has with liberation theology since the 1960's seriously.

The theme of development has drawn considerable ecumenical interest, at least since the world conference on Church and Society held in Geneva (1966). In 1968, at the Uppsala World Council of Churches Conference, an entire section (III) was devoted to "World Economic and Social Development” (Bosch 1991:434). The World Council of Churches and the Pontifical Commission on Justice and Peace established a committee on "Society, Development and Peace" (SODEPAX), clearly showing that development was a major priority for the ecumenical movement. Publications include In search of a theology of development: (a SODEPAX report) (1969) and Towards a theology of development: an annotated bibliography (1970).

Since the 1970s, the secular controversies over development have also stimulated debate in ecumenical circles. In the context of liberation theology, feminist theology and later postcolonial theology the very use of the term "development" was challenged, given that it was regarded as

1 John Klaasen is a lecturer in the department of Theology and Religion, Faculty of Arts, at the University of the Western Cape. He can be contacted at jsklaasen@uwc.ac.za. 
compromised upon the assumption of sustained economic growth and Western prescriptions for "economic development" in the so-called Third World. Bosch states that in Latin America: "Socio-politically, development was replaced by revolution; ecclesiastically and theologically by liberation theology...Soon 'liberation' was cropping up everywhere in the ecclesiastical landscape” (1991:434).

In the South African context there has understandably been considerable theological interest in discourse on development, partly because the crucial role of civil society and especially, of local churches in development, was widely accepted. One may identify various distinct contexts in which theological reflection on development have emerged since the 1990s.

Firstly, various reflections on community development may be found in missiological contributions emerging especially from within reformed churches by the early 1990s. This includes Die diens van Barmhartigheid en die Nederduitse Gereformeerde Kerk (1990). Secondly, under the leadership of Renier Koegelenberg the Ecumenical Foundation of Southern Africa produced a number of edited volumes and booklets following a series of conferences on church and development in the mid-1990s, given the introduction of the Reconstruction and Development Plan. These include Church and development: An interdisciplinary approach: perspectives from Southern Africa and Europe (1992), The reconstruction and development programme (RDP): the role of the Church, Civil society and NGO's: report to the third church and development programme (1995), and another publication titled The reconstruction and development programme (RDP): the role of the Church, Civil society and NGO's: report to the third church and development programme (1995). Thirdly, the University of KwaZulu-Natal established a Theology and Development Programme in the mid-1990s under the leadership of the late Professor Steve de Gruchy to reflect on issues of social transformation from a Christian theological perspective. After his death in 2010, this project was taken forward by Professor Beverly Haddad and Dr Clint le Bruyns. ${ }^{2}$ Stellenbosch University has established a number of programmes and research projects on congregational development and community development from around $2005 .{ }^{3}$ In addition, the complexities of discourse on church and development were explored in a number of publications edited by Ignatius Swart, including The churches and the development debate: the promise of a fourth generation approach (2000), Welfare, Religion and Gender in Post-apartheid South Africa - Constructing a South-North dialogue (SUN Press, 2010) and Religion and Social Development in Post-apartheid South Africa (SUN Press, 2012).

This article attempts to make a contribution to the discourse of missiology by engaging critically with the much debated studies of theology and

2 http://theologyanddevelopment.ukza.ac.za

3 academic.sun.ac.za/tsv/centres.html 
development. Firstly, I will analyse the two widely used definitions of development. Some commonalities of the two definitions are highlighted, but I also point out some weaknesses. Secondly, a theology of relationality that focuses on the Trinity, relationships and personhood is introduced. Thirdly, a more integral understanding of development surfaces from a discussion of perichoresis, personhood and ecclesia. Fourthly, some connections are made between human and social development and the Trinity and perichoresis. The strength of relating theology of relationality with development within missiology is part of the broad and holistic approach to development. This has missiological and ecclesiological implications for the mission of the church. I conclude that the church becomes an agent in the holistic development of persons and the worshipping community.

\section{Definitions of development}

In South Africa, as well as the rest of world, underdevelopment (especially social and economical) in many spheres of society is a major concern. South Africa has made major strides in areas such as housing, human rights, gender, culture, liberty, water and technology since the first democratic elections in 1994. These can be referred to as dimensions of development. Development is much broader however, and encompasses all of the above. This can be illustrated by the development of a definition used in the 2010 Human Development Report of Oxford Poverty and Human Development Initiative (Alkire 2010). It starts off in 1990 with the widely used definition of development by the economist, philosopher and Noble Laureate Amartya Sen, in which development is defined as "a process of expanding the real freedoms that people enjoy" (1999:3). Whilst the 1990 report consists of the clarifications of concepts, the 1991 to 1993 reports reflect the importance of human capital in the process. Between 1994 and 2010, human security, gender, economic growth, poverty, consumption, globalization, human rights, technology, democracy, millennium development goals, cultural liberty, international cooperation, water, climate change and migration, the dimensions of development, are firmly entrenched as the focus points. These dimensions have culminated into a more comprehensive statement of human development, as "Human development aims to expand people's freedom-the worthwhile capabilities people value-and to empower people to engage actively in development processes, on a shared planet. And it seeks to do in ways that appropriately advance equity, efficiency, sustainability and other key principles” (Alkire 2010:24).

Such a definition uses Sen's definition as a starting point and includes a broader sense of development than merely economic choices and selfish, individualistic and dissociated interests. While the focus is on involvement of the underdeveloped individuals, however, there is not a strong sense of 
mutually enriching interaction between the underdeveloped and oppressive structures and human forces. Development is not only abstract or deontological. The personal, individual and communitarian are at the core of personhood and integral to development processes.

A second definition of development is associated with one of the most comprehensive works on development in South Africa. This work is a direct result of two major projects that resulted in a substantial publication, Religion and social development in Post-.Apartheid South Africa (Swart 2010). Consisting of a group of specialists in the field, the use of development is closely linked with the international acclaimed scholar Korten's four generation strategic NGO intervention approach. This is of significance because of its different ways in which the church can engage in development, as well as the degree of involvement of the affected people. This project and related publications gives greater scope to development as social development. Social development is defined as "a process of planned social change designed to promote the wellbeing of the population as a whole in conjunction with a dynamic process of economic development" (Midgeley 1995:5).

This publication, as is also the case in other major works on the subject, for example The Oxford development project (1993) and Christian Aid (2010), has almost been reduced to economic and community development. Personhood is viewed as the expansion of choices for economic independence/development.

These two definitions are not mutually exclusive; instead, it points out some fundamental common threads. Firstly, development is people centred. The people are both the object, in other words the phenomenon to be developed, and the subject, who determines developmental processes. Secondly, both definitions imply a dynamic process with various stages, dimensions and resources rather than a closed system. Thirdly, development is broad and holistic and cannot be reduced to any one dimension.

The interplay between development and theology of relationality (psychological/social term) seeks to use the three common threads of the former two definitions. Instead of reducing development to an abstract phenomenon or one dimensional process, I will put personhood at the centre of development. A theology of relationality draws on the neglected Trinitarian confession, which was put at the centre of the nature of Jesus and his relationship with God, the Father, by The Cappadocian Fathers. I will also draw on the perichoretic paradigm by John of Damascus. Both The Cappadocians and John of Damascus provide a theological foundation for development as personhood.

Notwithstanding the major contributions that liberation theology (Boff 1995), ecumenical conferences and publications (EFSA 1992) and feminist 
theology (La Cugna) ${ }^{4}$ has made, a theology of relationships enhances the interplay between theology and development and has implications for missiology and ecclesiology. A relational theology includes a conceptualization of the interaction of God and humanity, the nature of the relation between individuals and the humans' interaction with the rest of creation (structures and other non- living beings).

Relational theology includes the ontology that God as triune in both substance and relationship has mutual and reciprocal interaction. It further presents human beings as persons and not absolute autonomous individuals whose freedom is limited to the capability of abstract reasoning. Finally, relational theology claims that the church, by its nature persons, is bound together in relationships through common worship. It is from these formative phenomena (Trinity, personhood and ecclesia) that theology forms the basis of mission and development.

\section{The Trinitarian God in relationship}

The re-emergence of the notions of the triune God in the twentieth century has taken a prominent place in theology. ${ }^{5}$ To this end, Greenwood claims that:

"A contemporary Christian apologetic needs to hold in tension an understanding of God as the source of all being, and the relationship between God and humanity, together with the whole of creation. It is within this context, in close association with the twentieth-century upsurge in exploration of the nature of God as triune, that new possibilities emerge for giving a satisfactory account of the relation between creator and creature" (1994:74).

This claim, that God is absolute and relational, is epistemological situated in two historical developments. Firstly, in the response to the Arian controversy by The Cappadocian Fathers (Basil the Great, bishop of Caesarea 329-379, Gregory of Nyssa 335-394 and Gregory of Nazianzus 329-390), Greenwood summarises the response of the Cappadocians "under three points". Firstly, they reformulate the conceptualization of the Trinity as three hypostases to emphasise the inseparable relation between Father, Son and Holy Spirit, instead of the mathematical or power relational. Hypostasis is used to distinguish between Father, Son and Holy Spirit (Van Hoozer 2010:143). Father, Son and Holy Spirit are one single being in

4 For an analysis of her views, see Medley, M.S., 2002, Imago Trinitatis: Toward a relational understanding of becoming human, University press of America, Maryland.

5 Koopman refers to Colle's (2001) portrayal of Karl Barth's formulation of the trinity as "the Father as the Revealer, the Son as the Revelation and the Spirit as the Revealedness" and Karl Rahner's formulation of "economic Trinity is the immanent Trinity and the immanent Trinity is the economic Trinity”. Koopman also cites Gunton's (1993) references to Lossky and Zizioulas (Orthodox), Kasper Hill (Roman Catholic), Jenson (Lutheran), Moltmann (Reformed) and Brown (Anglican), 2008. 
communion. This unity and diversity is symbolically presented as the human reproduction and breath or procession. Analogically, one can speak of the universal and its particulars. The Father is that from which the Spirit and Son derives. Secondly, persons are not only relational. Persons have stories, actions and speech, which make them agents who are responsive and to whom responses are made. "Persons are not therefore relations all the way down” (Van Hoozer 2010:143). Thirdly, the Cappadocians give a distinct meaning to how a person relates to difference and freedom. A person is different from an individual in so far as the latter is measurable by the degree of independence, while the former is essentially, not only, characterised by the relation with others (Greenwood 1994:82, Van Hoozer 2010:144).

This distinct substance of unity in diversity is further explained by the perichoretic paradigm of persons in relation first used by John of Damascus. Speidell suggests that John of Damascus uses perichoresis as "the reciprocal giving and receiving of free communion between Father, Son and Spirit" (1994:283-284). This implies that the persons do not merely exist in and through themselves, but through voluntary invitation, in relationship with the others.

The view of a person here differs from the Enlightenment emphasis on the individuality of humans. The individual is independent or separated from others, while a person finds identity through its interaction with others. God is not the "impersonal, mechanistic one" but one in free relations with one another and creation (Speidell 1994:285).

Some criticisms against this Trinitarian formula and perichoresis must be taken seriously. Firstly, relationality alone is not equivalent to God's nature. This would be reducing God "into his interpersonal communion or onto-relationality". Secondly, it is also difficult to maintain the divine oneness and the divine threeness at the same time (Van Hoozer 2010:143).

With regard to perichoresis, one of the common criticisms is the preference that is given to the person of the Father in the Trinity, as in the tradition of the fourth and fifth century Eastern theologians. To imply that the Son and the Spirit derives from the Father (as the arche) immediately denotes the Son and the Spirit to subordination. This formulation has implications for feminist theologians, who points out the hierarchical powers in such a theology. A second and closely related criticism is a hierarchy of divinity, which can result in the detachment of the Father to the world (Medley 2002:55-56). A third criticism relates to Feuerbach's idea of God as a projection of humanity's need for social relations (Cipriani 2000:21).

Three comments need to be made. Firstly, the Cappadocians never intended to exhaust the nature of God as person. They do make a strong theological case that God is onto-relational. Secondly, perichoresis does not 
imply a hierarchy of influence or initiation, but is mutual, free and reciprocal interaction. Thirdly, in relation to Feuerbach's critique, one can infer that humanity is social in nature and in the likeness of God.

\section{Personhood as individuals in relationship}

The Enlightenment scientific, technological and free individualism has found renewed criticism from theologians and scientists alike. The Christian tradition finds itself in a paradigm shift that questions the absolute autonomous individual as the most objective and highest form of being. Being is not equivalent to self-determination, but the extent to which one mirrors the likeness of God. The likeness of God here refers to Trinitarian ontology of relation amongst Father, Son and Holy Spirit.

Unlike many sociologists, such as Edward Shils' (1981), attempt to define personhood as human beings' ability to be in the center, philosophers such as Gyekye (1997), who terms it as a part of a limited community, or theologians such as Mbiti (1975), who describes personhood as completely derived from community, personhood is defined by humans' relationships with the Trinity. In other words, personhood is theonomous. Personhood here means that humans are created in and by God and its goal is towards God.

By placing personhood as individuals in society, it creates coercion and subsequently limits freedom of development. By attempting to define personhood in terms of the individual being part of the limited community, Gyekye gives priority to individualism over community. Mbiti's overemphasis of community reduces the individual to a passive recipient. In all three notions of personhood, the lack of voluntary active agency in a reciprocal, dynamic process is evident.

A theology of relationality embeds personhood in the creative tension between particular and universal or the individual and communal. This notion of personhood does not deny the distinction of the individuals, but it places the distinctiveness in the continuous process of development. Personhood is not individualism or societal because it is always in relation with other person(s). Personhood as process is always eschatological and develops to its full potential in relation to past, present and future.

Personhood used in this form does not reject person. While personhood refers to what a person is, person refers to the identity of the person. A person possesses a substance which is personhood. In the same way, personhood is expressed in specific ways that gives identity. In a sense, the person will express individual, particular, unique and different qualities in a process of mutual enrichment. Personhood, although not dependent on these particularities, can be common to different persons. Personhood and person are used here almost interchangeably with the understanding that personhood implies that a person has the capacity to have relationships with 
others. While we cannot reduce personhood to relationships, the identity of a person is relational (Van Hoozer 2010:144).

Personhood that is formed and sustained in such creative tension can be termed "narrated personhood". It is "narrated personhood" because it is defined from within the historical and critical engaging development of the person. The person is part of a narrative that includes other persons and usually is open to relations with other persons. Persons within a story form community where relations develop the potential towards a greater sense of personhood. Such a community is defined by Macmurray, as quoted by Speidel, as "the unity of persons" that retains both individuality - the other is genuinely other - and mutuality of relation (including equality of intention, rather than de facto equality). "A community, accepts" "the ideal of a personal ... a universal community in which each cares for all and no one for himself” (1994:287).

\section{Ecclesia}

Notwithstanding the critique that community can be idealized (Speidel 1994:287) or unrealistic, the Christian narrative of the gospel, embedded in koinonia, assumes community where difference is not absorbed into unity, for example in the case of ideology. Greenwood suggests that the ecclesia is an alternative to the Enlightenment secular wisdom of individualism and collectivism. The ecclesia "is possessed by a vision of God and the created order as open and engaged in a life-process. Unity is not to be equated with the denial of difference or the reduction of them all to one, but speaks of the mutual intercommunion and interpenetration of elements of difference" (1994:88). Even the differences is a result of our relations and its significance is not to emphasise the independent, complete product, but to the person in formation, through relation with other selves.

When differences take on such an authentic role, both selves develop in their "narrated personhood" as vulnerable persons. When the other is seen, heard, spoken to and acted upon, it is experienced beyond the physical appearance. Instead the vulnerable other, according to La Cugna, "evokes mystery, compassion, reciprocity, and obligation. It is as we look into another person's eyes and gaze upon the face of another person that we see with the 'eyes of the heart' and stand in openness before her and his ineffable and inexhaustible mystery” (Medley 2002:177).

This is a far cry from the autonomous individual or collection of individuals that is bound together for the benefit of the individual or common causes. The former denies the creativity of relationships and the latter "reduces all members of human society to the status of disposable cogs in the machine of a corporate enterprise" (Greenwood 1994:89). Vulnerability, on the other hand, creates space for open, trustworthy and loving relations. 
Such personhood is based upon the Trinitarian God. Individuals mirror God in both its Missio Dei and Koinonia. Persons are called out to be the embodiment of God and act accordingly. As God is three persons in relation, the ecclesia, which is the embodiment of God, is a community of personhood that is relational.

\section{All reality is relational}

It is not only personhood and the church that is rooted in Trinitarian ontology, but the rest of "reality" forms part of the greater narrative of Father, Son and Holy Spirit. Both theologians and scientists must move beyond the antagonisms that have dominated the modern period. In a post-modern period theologians must find ways to convey the gospel message in critical engagement with other sciences and disciplines. Efforts such as Moltmann's (1979) open, creative process of reality, Millbank's (1990) critical engagement between theology and social theories and Boff's (1995) move away from an anthropocentric to an integral cosmic approach brings necessary knowledge to any conversation about theology and reality. These three approaches represent attempts to show how relations between humans and the rest of creation are embedded in the Trinity.

Leonardo Boff, one of the most influential liberation theologians, uses "the perichoretic communion of the Trinity" to demonstrate how humans relate to ecology in an interdependent manner for mutual existence. For Boff, God is Trinity from which the whole created order emanates. To this effect, Boff states:

"It means the tendency in nature to form wholes that are more than the sum of the parts. Here we have the synthesis that orders, organises, regulates, and completes the parts in a whole and relates each whole to another, even greater whole. Holistic ecology as a practise and theory comprises and relates all existents one to another and with the environment” (1995:11).

Boff claims that humans relate to other forms of being in a manner that affirms "the mutual love and knowledge, life and freedom, and interpenetration of the divine persons in, by, through and for one another ... a bond of communion that he claims nonetheless values individuality and accept differences" (Speidell 1994:290).

In socialist and capitalist societies, for example, structures and systems do not reflect the mutual love (Speidell 1994:290). Value for individuality and acceptance of diversity need to be transformed. Capitalist systems and societies that denies Trinitarian communion protects the property owning classes at the expense of the overwhelming majority working class, whose personhood is treated as impersonal beings. This is a direct result of the relation between humans and social and other structures that predetermine society. It is also a direct result of the kind of relation of the difference drawn between the personhood of the different classes. The same can be 
deduced from socialist societies, which subjugate the individual against the collective. Such societies exchange equality amongst persons for coercion towards the common good. Structures in such communities perform a different, yet equally severe, form of impersonal relations.

Boff's use of perichoresis both affirms relations between persons and the rest of creation as the potential to love mutually, self-giving, generosity, openness, inclusiveness, diversity, and criticises individualism, socialism, selfishness and oppression. Like the relations amongst persons, relations between persons and the rest of creation is characterised by vulnerability and mutual indwelling.

\section{How does the Trinity and perichoresis relate to human and social development?}

Firstly, development is people centred. Ontology of Trinity and perichoresis affirm the status of persons as agents in their own development. Instead of individualism or collectivism, persons refer to personhood. In theological terms, the people here are the ecclesia, called out to embody the Trinity as hypostases and relationship.

Personhood is central to the process of development and goes beyond any one dimension of development. Personhood implies the involvement of people for the well-being of the whole person and that of the whole community. Personhood is not defined by the selfish gain for the individual, but in the reciprocal enrichment that affirms the interdependency of the individual.

Personhood is not limited to relations between humans, individuals also relate to non-human communities. "Becoming a person is thus a transformative process of entering into mutuality and solidarity with ever-wider circles of communion that are created and nourished by the Spirit. We become iconic of the Divine Life in our mutual and just relating to each other, in our communities, and in relationship with the earth. Becoming truly human and living in communion with all the communities of the earth is inseparable" (Speidell 1994:179). People centeredness does not mean the selfish application of power by individuals or groups to impose universality or exploit human and non-human communities. Personhood understood as mirroring Trinitarian ontology as persons in relationship, is rooted in the responsible, mutual enriching relationship it has with the other. Instead of viewing non-human communities as products for consumption by humanity (Mbiti 1975), the relationship is one of mutual care and responsibility.

Personhood also assumes a relationship of vulnerability with other individuals and communities. Vulnerability refers to the openness for the advancement of the potential of both parties in the relationship to be free. 
Vulnerability is an invitation to be enriched, empowered, influenced, grow, expand and transformation.

Secondly, both definitions imply a process, instead of system. Trinitarian ontology implicitly includes a dynamic process that involve the past, present and future. It is eschatological. A dynamic process does not deny particularity, but it also does not treat it as absolute.

Speidel draws from Eastern Orthodoxy's distinction between the terms "image" and "likeness" to describe creation in Genesis 1:26-27. The former refers to a created given and the latter to a potential future (1994:179). Created could be equated to a closed system, which assumes a static form. Likeness, on the other hand, assumes movement toward perfection. Spiedel quotes Hilkerk to emphasise the notion of calling: "An eschatological perspective reminds us that the 'image of God describes not a primordial state from which human beings fell, but the destiny toward which human community is called'” (1994:180).

Eschatology reminds us that although human beings are made in the likeness of God, personhood has not been fully realised. Personhood that is beyond economic, social or moral "capabilities" is both a calling and vocation. To this end, personhood is both active and contemplative. We practice faithful vocations when we live in the present life in "friendship with God and in solidarity with all of God's astonishingly diverse creation. It is to practice those virtues, attitudes, intentions, and affections that seem authentically to conform to the Communion at the heart of all communion, although as yet incompletely and imperfectly” (Speidel 1994:181).

\section{Conclusion}

A relational theology's approach to development points to development as broad and holistic and contributes to the mission of the church and missiology. Development cannot be reduced to one dimension. Sen's definition of development restricts development to the increase of the choices of the individual. Individual refers to the autonomous individual who finds individual freedom in the multiple choices made available through abstract reasoning. Alkire points out that Robeyn supports Sen's ethical individualism (2010:20-21). By ethical individualism, she implies that individuals are the only objects of moral concern. Whilst Robeyn rightly argues that other forms of individualism, like methodological individualism and ontological individualism, can ignore inequality within the group, individualism is self-centred and self-determining. Development happens in relationships. Unlike the capability approach that compartmentalizes the person, development of the person happens in relationships with other persons and the rest of creation, including structures, societal units or material resources. 
Social development puts more emphasis on the relation between group dynamics and economics. This has resulted in a shift towards social welfare in a post- Apartheid South Africa. The state, religions and non-governmental organisations has co-operated, successfully, to address the social needs of society, both through policy advocacy and practical activities. EFSA, for example, has been at the forefront of promoting the collaboration between state and religion (Swart 2010:15). Swart points out a number of shortcomings with such collaborations. Two of these criticisms are that in most cases, the religious sector follows the dominant ideological trends and that religion loses its critical voice. Whilst I agree with these important criticisms, Swart fails in his insistence that the task of the church is "to pose a serious moral challenge to the vast and ever-increasing disparity between rich and poor in the country" (2010:26).

Mission rooted in a theology of relationship has a much more holistic approach than the two approaches of development by Sen and Korten, whose emphasis is merely social or economic development. Personhood encompasses every facet of a persons' being. When development is restricted to one dimension of the person, it tends to enforce uniformity and universality. Personhood in relationship involves a creative, dynamic reality of particularity and universality, individual and communal, uniqueness and difference. Every dimension of the individual must be developed, so that the person can participate as agent. Such participation is possible when the person is actively involved in the creating of space and time for mutual growth.

The church becomes an important community for the development of persons. Through its mission, the sacraments, ecclesiastical ministries, organisations, worship, social responsibilities and teachings, the church is an agent of development. The church is actively involved in the holistic development of its worshipping community.

\section{References}

Alkire, L. 2010. Report of Oxford Human Development report. Oxford.

Bauer, G. 1970. Towards a theology of development: an annotated bibliography. Geneva: Ecumenical centre, publications department.

Boff, L. 1995. Ecology and liberation: A new paradigm. Maryknoll: Orbis.

Bosch, D. J. 1991, Transforming mission: Paradigm shifts in theology and mission. Maryknoll: Orbis.

Cipriani, R. 2000. Sociology of religion: An historical introduction. New York: Aldine Gruyter.

Clifford, P. 2010. Theology and international development. Oxford: Christian Aid Report.

Committee on Society, Development and Peace, 1969. In search of a theology of development: A SODEPAX Report, Geneva: Sodepax. 
De Klerk, J.J. (red.) 1990. Die diens van barmhartigheid en die Nederduitse Gereformeerde Kerk. Cape Town: NG Kerk-Uitgewers.

Greenwood, R. 1994. Transforming priesthood: A new theology of mission and ministry. London: SPCK.

Gyekye, K. 1997. Tradition and modernity: Philosophical reflections on the African experience. New York: Oxford university press.

Koegelenberg, R.A. (ed.) 1992. Church and development: An interdisciplinary approach: perspectives from Southern Africa and Europe. Report of the First Church and development conference. Bellville: EFSA.

Koegelenberg, R., Pityana, B., Kobia, S. \& Batista, I. 1995, The reconstruction and development programme (RDP): The role of the Church, Civil society and NGO's: report to third church and development programme. Bellville: EFSA.

Koegelenberg, R., Govender, S., (et al). 1995. The reconstruction and development programme (RDP): The role of the Church, Civil society and NGO's: report to third church and development programme. Bellville: EFSA.

Koopman, N. 2008. Vulnerable Church in a vulnerable world? Journal of Reformed theology 2(3): 240-254.

Mbiti, J.S. 1975. Introduction to African religion. London: Heinemann educational books.

Medley, M.S. 2002. Imago Trinitatis: Toward a relational understanding of becoming human, Maryland: University press of America.

Midgeley, J. 1995. The social development in social welfare. California: SAGE publications.

Millbank, J. 1990. Theology and social theory: Beyond secular reason. Oxford: Blackwell.

Moltmann, J. 1979. The future of creation. London: SCM Press.

Sen, A. 1999. Development as freedom. Oxford: Oxford University Press.

Shils, E. 1981. Tradition, London: Faber and Faber.

Speidell, T.H. 1994. A Trinitarian ontology of persons in society. Scottish journal of theology, 47(3), Edinburgh: T\&T Clark.

Swart, I. 2000. The churches and the development: The promise of a Fourth generation approach. Unpublished D Phil dissertation. Stellenbosch: Stellenbosch University.

Swart, I. (ed.) 2010. Religion and social development in post-apartheid South Africa. Stellenbosch: SUN Press.

Swart, I. (ed.) 2012. Welfare, religion and gender in post-apartheid South Africa, Stellenbosch: SUN Press.

Van Hoozer, K.J. 2010. Demythologizing theology: Divine action, passion and authorship. Cambridge: Cambridge University Press. 